\title{
PENGARUH UKURAN PERUSAHAAN, PERTUMBUHAN ASSET, PROFITABILITAS DAN PERTUMBUHAN PENJUALAN TERHADAP STRUKTUR MODAL PERUSAHAAN COSMETICS AND HOUSEHOLD DI BURSA EFEK INDONESIA
}

\author{
Safitri Ana Marfuah, Siti Nurlaela \\ Fakultas Ekonomi Universitas Islam Batik Surakarta \\ Email: dra_nurlaela@yahoo.com
}

\begin{abstract}
Capital markets are trading activity related to capital, such as bonds and securities. This market serves to connect investors, companies and government institutions through longterm financial instruments trading. Capital structure decisions are not thorough and will result in high capital that will be received by the company and will affect the decline in profitability, it will threaten the company's financial position. This study has the objective to determine whether there is influence between the size of the company (firm size), the growth of assets (assets growth), profitability (return on equity) and sales growth (sales growth) on the capital structure (debt equity ratio) on a company to go public namely in the sectors listed Cosmetics and Houshold Indonesia Stock Exchange (BEI). The method used is quantitative, meaning researchers will quantify all of the data obtained. The samples used in this study 6 companies with the financial statements between 2010 to 2015. The sampling method in this research is purposive sampling with criteria in accordance with the objectives of the study. Analysis of the data used in this study using a method that consists of classic assumption test, multiple linear regression analysis, and test the hypothesis that simultaneous partial test and test. Results obtained from the partial test showed that the variables significantly influence the size of the company's capital structure. Asset growth variable has no significant effect on the capital structure. Variables significantly affect the profitability of capital structure. Variable sales growth known to have no significant effect on the capital structure. While the results obtained from testing simultaneously is the independent variable (the independent variable) used in this study (size of companies, growth in assets, profitability, sales growth) have a significant effect on the dependent variable (variable binder) that the capital structure.
\end{abstract} Keywords: firm size, asset growth, profitability, sales growth.

\section{PENDAHULUAN}

Pasar modal adalah kegiatan yang berhubungan dengan perdagangan modal, seperti obligasi dan efek. Pasar ini berfungsi untuk menghubungkan investor, perusahaan dan institusi pemerintah melalui perdagangan instrumen keuangan jangka panjang. Pasar modal merupakan salah satu alternatif investasi bagi para investor. Menurut catatan BEI jumlah investor lokal mencapai $60 \%$ dan investor asing $40 \%$ dari total investor pasar modal. Dari data tersebut cukup ideal dan seimbang antara investor asing dan 
investor lokal. Konsumsi masyarakat kelas menengah mendorong brand kosmetik menjadi salah satu kebutuhan. Dengan meningkatnya kebutuhan masyarakat, hal ini berpengaruh terhadap perusahaanperusahaan terkait termasuk brand kosmetik yang menjadi pilihan masyarakat. Wanita selalu identik dengan keindahan, keanggunan, dan keagungan. Wanita diibaratkan perhiasan bagi dunia, begitu berharganya wanita sehingga dari sisi manapun dan dari hal sekecil apapun wanita selalu menjadi pusat perhatian. Namun dibalik keindahan tersebut kosmetik sangatlah berperan penting bagi kecantikannya.

Untuk penelitian ini penulis memiliki beberapa perbedaan dengan penelitian sebelumnya. Perbedaan terletak pada penggunaan variabel independen, banyaknya sampel yang digunakan, dan periode penelitian. Pramesti, Nurlaela, (2016), Hasil penelitian menyatakan bahwa secara parsial variabel Current Ratio tidak berpengaruh terhadap profitabilitas (Return On Asset), sedangkan variabel Debt To Equity Ratio, Total Asset Turnover dan Firm Size berpengaruh terhadap Profitabilitas (Return On Asset). Rahadia, Nurlaela. (2013) hasil penelitian Pengaruh Likuiditas, Profitabilitas, Solvabilitas, Dan Ukuran Perusahaan Terhadap Harga Saham Pada Perusahaan Manufaktur Yang Terdaftar Di Bursa Efek Indonesia . Pada penelitian Zuhro,F (2016) variabel independen yang digunakan yaitu ukuran perusahaan, pertumbuhan aset, dan profitabilitas, sampel yang digunakan yaitu 3 perusahaan cosmetics and household yang terdaftar di BEI dengan periode tahun penelitian 2010-2014. Pada penelitian Sari, A.N (2016) variabel independen yang digunakan yaitu profitabilitas, likuiditas, pertumbuhan aset dan ukuran perusahaan, sampel yang digunakan yaitu 12 perusahaan otomotif yang terdaftar di BEI dengan periode tahun penelitian 20102014. Dari penelitian Nastiti,R.D (2016) variabel independen yang digunakan yaitu struktur aset, likuiditas, profitabilitas, ukuran perusahaan, dan pertumbuhan penjualan, sampel yang digunakan yaitu 17 perusahaan sub sektor makanan dan minuman yang terdaftar di BEI periode tahun penelitian 2011-2014. Dari penelitian Atiqoh,Z (2016) variabel independen yang digunakan yaitu pengaruh kinerja keuangan, Size, pertumbuhan penjualan, dan kepemilikan saham, sampel yang digunakan yaitu 44 perusahaan manufaktur yang terdaftar di BEI dengan periode tahun penelitian 20112014. Sedangkan pada penelitian ini menggunakan variabel independen yaitu ukuran perusahaan, pertum buhan aset, profitabilitas, dan pertumbuhan penjualan, sampel yang digunakan yaitu 6 perusahaan cosmetics and household yang terdaftar $\mathrm{di}$ BEI dengan periode tahun penelitian 20102015.

Keputusan struktur modal yang tidak teliti dan tepat akan mengakibatkan tingginya modal yang akan diterima oleh perusahaan dan akan mempengaruhi turunnya profitabilitas, hal tersebut akan mengancam posisi keuangan perusahaan. Berdasarkan latar belakang yang dikemukakan diatas, penulis memutuskan untuk melakukan penelitian lebih lanjut. Masih terdapat perbedaan dari penelitianpenelitian sebelumnya. Tujuan dari penelitian ini adalah sebagai berikut: Untuk mengetahui pengaruh ukuran perusahaan terhadap struktur modal pada 
perusahaan Cosmetics and Household yang terdaftar di Bursa Efek Indonesia. Untuk mengetahui pengaruh pertumbuhan aset terhadap struktur modal pada perusahaan Cosmetics and Household yang terdaftar di Bursa Efek Indonesia. Untuk mengetahui pengaruh profitabilitas terhadap struktur modal pada perusahaan Cosmetics and Household yang terdaftar di Bursa Efek Indonesia. Untuk mengetahui pengaruh pertumbuhan penjualan terhadap struktur modal pada perusahaan Cosmetics and Household yang terdaftar di Bursa Efek Indonesia.

\section{Perumusan Hipotesis}

1. Hubungan Ukuran Perusahaan dengan Struktur Modal

$\mathrm{H}_{1}$ : Terdapat pengaruh signifikan antara ukuran perusahaan (firm size) terhadap struktur modal.

2. Hubungan Pertumbuhan Aset dengan Struktur Modal

$\mathrm{H}_{2}$ : Terdapat pengaruh signifikan antara pertumbuhan aset (assets growth) terhadap struktur modal.

3. Hubungan Profitabilitas dengan Struktur Modal

$\mathrm{H}_{3}$ : Terdapat pengaruh signifikan antara profitabilitas terhadap struktur modal.

4. Hubungan Pertumbuhan Penjualan dengan Struktur Modal

$\mathrm{H}_{4}$ : Terdapat pengaruh signifikan antara pertumbuhan penjualan terhadap struktur modal.

\section{METODOE PENELITIAN}

Dalam penelitian ini, jenis penelitian yang digunakan adalah penelitian kuantitatif, artinya peneliti akan menguantitatifkan semua data yang didapat. Kemudian diterjemahkan melalui pengolahan secara statistik data kuantitatif yaitu data yang berupa bilangan, nilainya bersifat variatif. Data yang digunakan merupakan angka dari ukuran perusahaan (size), pertumbuhan aset (assets growth), profitabilitas (ROA), pertumbuhan penjualan, dan struktur modal (DER).

Ukuran struktur modal merujuk pada Brigham dan Houston (2009:117), yaitu DER dengan formula:

$$
D E R=\underline{\text { Total Hutang }} \times 100 \%
$$

\section{Total Ekuitas}

Ukuran perusahaan merujuk pada Weston J. Fred dan Thomas (2008), yaitu size dengan menggunkan rumus; Size = Ln (Total Asset)

Ukuran tingkat petumbuhan aset merujuk pada Weston J. Fred dan Thomas (2008) dengan menggunakan rumus sebagai berikut:

$$
A G=\frac{\text { Total Asset } \mathrm{t}-\text { Total Asset }-1}{\text { Total Asset } \mathrm{t}-1} \times 100 \%
$$

Ukuran profitabilitas merujuk pada Weston J.Fred dan Thomas (2008), yaitu Return On Equity (ROE) dengan menggunakan rumus sebagai berikut:

$$
R O E=\frac{\text { EAT (Earning After Tax })}{\text { Total Ekuitas }}
$$

Ukuran pertumbuhan penjualan ini dapat dihitung sebagai berikut (Priambodo et al. 2014):

Pertumbuhan penjualan $=\underline{\text { Penjualan }(\mathrm{t})-\text { Penjualan }(\mathrm{t}-1)}$ Penjualan (t-1)

Data yang digunakan dalam penelitian ini adalah data sekunder berupa laporan keuangan tahunan yang dipublikasikan oleh perusahaan Cosmetics and Household yang terdaftar di Bursa Efek Indonesia (BEI) pada periode tahun 2010-2015. Metode purposive sampling 
merupakan metode pemilihan sampel yang dapat memberikan informasi yang dibutuhkan dalam penelitian berdasarkan kriteria atau pertimbangan tertentu sesuai dengan sasaran penelitian. Kriteria yang disebutkan yaitu (1) Perusahaan Cosmetics and Household yang terdaftar di BEI (2) Prusahaan yang mempublikasikan laporan keuangan selama periode penelitian.

Analisis regresi berganda ini digunakan untuk memprediksi satu variabel tergantung berdasarkan dua atau lebih variabel bebas (Suliyanto, 2011:37). Pada penelitian ini, analisis regresi berganda dengan bantuan SPSS 22 untuk mengolah data merupakan alat analisis yang dilakukan untuk mengetahui pengaruh dari ukuran perusahaan, pertumbuhan aset, profitabilitas, dan pertumbuhan penjualan terhadap struktur modal. Bentuk umum persamaan regresi linier berganda yang digunakan dalam penelitian ini, ditentukan sebagai berikut:

$$
\mathrm{DER}=\mathrm{a}+\mathrm{b} 1 \mathrm{UP}+\mathrm{b} 2 \mathrm{PA}+\mathrm{b} 3 \mathrm{ROE}+\mathrm{b} 4 \mathrm{PP}+\mathrm{e}
$$

$$
\begin{array}{ll}
\text { Dimana: } & \\
\mathrm{DER} & =\text { Debt To Equity Ratio } \\
\mathrm{a} & =\text { Konstanta } \\
\mathrm{b} 1,2,3,4 & =\text { Koefisien Regresi } \\
\mathrm{UP} & =\text { Ukuran Perusahaan (Firm Size) } \\
\mathrm{PA} & =\text { Pertumbuhan Aset (Assets Growth) } \\
\mathrm{ROE} & =\text { Return On Equity } \\
\mathrm{PP} & =\text { Pertumbuhan Penjualan } \\
\mathrm{e} & =\text { Faktor Lain yang Mempengaruhi }
\end{array}
$$

Uji t digunakan untuk mengetahui seberapa jauh pengaruh dari variabel independen (X) terhadap veriabel dependen (Y) secara parsial. Pengujian hipotesis akan dilakukan dengan menggunakan tingkat signifikasi sebesar $0,05(\mathrm{a}=5 \%)$.

\section{HASIL PENELITIAN DAN PEMBAHASAN}

\section{Deskripsi Umum Data Penelitian}

Penelitian ini menggunakan data sekunder. Data sekunder yang digunakan dalam penelitian ini adalah laporan keuangan tahunan perusahaan Cosmetics and Household (Kosmetik dan Kebutuhan Rumah Tangga) pada tahun 2010 - 2015 yang terdaftar di Bursa Efek Indonesia (BEI). Daftar perusahaan yang menjadi sampel dalam penelitian ini adalah sebagai berikut : 
Tabel 1

Daftar 6 Perusahaan Sampel Penelitian

\begin{tabular}{|c|c|l|}
\hline No & Kode Perusahaan & \multicolumn{1}{|c|}{ Nama Emiten } \\
\hline 1 & ADES & PT. Akasha Wira International, Tbk \\
\hline 2 & KINO & PT. Kino Indonesia, Tbk \\
\hline 3 & MBTO & PT. Martina Berto, Tbk \\
\hline 4 & MRAT & PT. Mustika Ratu, Tbk \\
\hline 5 & TCID & PT. Mandom Indonesia, Tbk \\
\hline 6 & UNVR & PT. Unilever Indonesia, Tbk \\
\hline
\end{tabular}

Sumber : www.idx.co.id

\section{Hasil Pengujian Hipotesis / Penelitian}

1. Uji Asumsi Klasik

a. Uji Normalitas Data

Uji Normalitas bertujuan untuk menguji apakah dalam model regresi, variabel pengganggu atau residual memiliki distribusi normal. Untuk menguji apakah data berdistribusi normal atau tidak dilakukan uji statistik KolmogorovSmirnorv Test. Residual berdistribusi normal jika memiliki nilai signifikasi > 0,05. Hasil dari pengujian uji normalitas data adalah sebagai berikut :

Tabel 2

Hasil Uji Normalitas

\begin{tabular}{lccc}
\hline & $\begin{array}{c}\text { Unstandardized } \\
\text { Residual }\end{array}$ & Standar & Keterangan \\
\hline $\mathrm{N}$ & 32 & & Data Normal \\
Test Statistic & 1.166 & & \\
$\begin{array}{l}\text { Asymp. Sig. (2- } \\
\text { tailed) }\end{array}$ & $.249^{\mathrm{c}}$ & $>.0,05$ & \\
\hline
\end{tabular}

Sumber : Lampiran

Berdasarkan hasil yang didapatkan dari uji normalitas data pada tabel 2 di atas yang menggunakan One-Sample Kolmogorov-Smirnov Test dapat disimpulkan bahwa variabel pengganggu atau residual mempunyai distribusi normal karena memiliki nilai signifikasi > 0,05 yaitu sebesar 0,249.

b. Uji Multikolinearitas
Uji Multikolinearitas bertujuan untuk menguji apakah model regresi ditemukan adanya korelasi antar variabel bebas (independen). Jika nilai VIF < 10, maka dapat disimpulkan data bebas dari gejala multikolinearitas. Hasil dari pengujian uji multikolinearitas adalah sebagai berikut: 
Tabel 3

Uji Multikolinearitas

\begin{tabular}{cccc}
\hline Beta & VIF & Standar & Ketrangan \\
\hline UP & 2.014 & $<10$ & Tidak terjdi multikolinearitas \\
PA & 1.305 & $<10$ & Tidak terjdi multikolinearitas \\
ROE & 1.583 & $<10$ & Tidak terjdi multikolinearitas \\
PP & 1.511 & $<10$ & Tidak terjdi multikolinearitas \\
\hline
\end{tabular}

Sumber : Lampiran

Berdasarkan hasil yang didapatkan dari uji multikolinearitas data pada tabel 5 diatas menunjukkan bahwa Ukuran Perusahaan (UP), Pertumbuhan Aset (PA), Return On Equity (ROE), dan Pertumbuhan Penjualan (PP) memiliki nilai VIF < 10. Maka dapat disimpulkan bahwa model regresi ini bebas dari gejala multikolinearitas.

c. Uji Autokorelasi

Uji Autokorelasi adalah untuk mengetahui adanya korelasi antara variabel pengganggu pada periode $\mathrm{t}$ dengan variabel $\mathrm{t}-1$ (sebelumnya) dengan melihat nilai dari DW (Durbin Watson). Jika nilai DW $<-2$ maka terjadi autokorelasi positif, jika nilai DW < 2 maka tidak ada autokorelasi, jika nilai DW > 2 maka terjadi autokorelasi negatif. Hasil dari pengujian uji autokorelasi adalah sebagai berikut :

Tabel 4

Hasil Uji Autokorelasi

\begin{tabular}{ccc}
\hline Model & Durbin Watson & Keterangan \\
\hline 1 & 1.944 & Tidak Terjadi Autokorelasi \\
\hline
\end{tabular}

Sumber : Lampiran

Berdasarkan hasil yang didapatkan dari uji autokorelasi pada tabel 5 diatas menunjukkan bahwa nilai Durbin Watson sebesar 1.944, maka dapat disimpulkan bahwa tidak terjadi autokorelasi di dalam model regresi, karena nilai DW $<2$.

d. Uji Heteroskedastisitas

Uji Heteroskedastisitas bertujuan menguji apakah dalam model regresi terjadi ketidaksamaan variance dari residual satu pengamatan ke pengamatan yang lain. Tidak terjadi heteroskedastisitas apabila tidak ada pola yang jelas, serta titik - titik menyebar diatas dan dibawah angka 0 pada sumbu Y. Hasil dari pengujian uji heteroskedastisitas adalah sebagai berikut : 


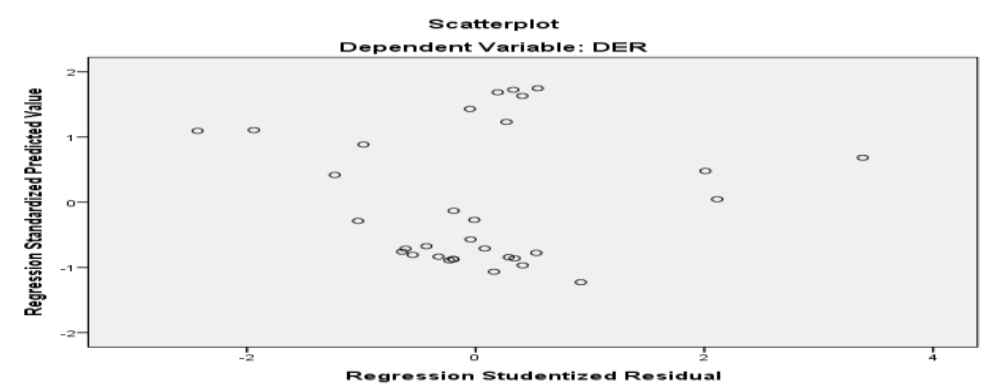

Gambar 1. Grafik Plot

\begin{abstract}
Berdasarkan hasil uji heteroskedastisitas, yang ditunjukkan oleh grafik plot diatas menunjukkan bahwa tidak ada pola yang jelas, serta titik - titik menyebar diatas dan dibawah angka 0 pada sumbu Y, maka dapat disimpulkan bahwa Tidak terjadi heteroskedastisitas di dalam model regresi.
\end{abstract}

2. Uji Hipotesis a. Analisis Regresi Linier Berganda

Pada penelitian ini, analisis regresi linier berganda merupakan alat analisis yang dilakukan untuk mengetahui pengaruh dari ukuran perusahaan, pertumbuhan aset, profitabilitas, dan pertumbuhan penjualan terhadap struktur modal. Hasil regresi linier berganda dapat dilihat sebagai berikut:

Tabel 5

Hasil Analisis Regresi Linier berganda

\begin{tabular}{cc}
\hline Model & B \\
\hline (Constant) & 68.719 \\
UP & -2.878 \\
PA & 0.569 \\
ROE & 23.790 \\
PP & 0.048
\end{tabular}

Sumber : Lampiran

Berdasarkan hasi pengujian regresi linier berganda yang dapat dilihat pada tabel 7 diatas, maka didapat persamaan regresi sebagai berikut :

$$
\mathrm{DER}=68.719-2.878 \mathrm{UP}+
$$

$$
0.569 \mathrm{PA}+23.790 \mathrm{ROE}+0.048 \mathrm{PP}
$$

Berdasarkan persamaan regresi linier berganda yang telah terbentuk tersebut diatas dapat dijabarkan sebagai berikut :
1) Konstanta yang diperoleh dari persamaan regrresi diatas sebesar 68.719 menunjukkan bahwa jika semua variabel independen bernilai 0 , maka dapat diartikan struktur modal akan bernilai sebesar 68.719.

2) Koefisien regresi dari variabel ukuran perusahaan bernilai negatif yaitu sebesar -2.878. Hal tersebut dapat diartikan bahwa apabila variabel 
ukuran perusahaan mengalami kenaikan satu satuan dengan asumsi variabel yang lain tetap (konstan), maka struktur modal akan mengalami penurunan sebesar -2.878 .

3) Koefisien regresi dari variabel pertumbuhan aset bernilai sebesar 0.569. Hal tersebut dapat diartikan bahwa apabila variabel ukuran perusahaan mengalami kenaikan satu satuan dengan asumsi variabel yang lain tetap (konstan), maka struktur modal akan mengalami penurunan sebesar 0.569 .

4) Koefisien regresi dari variabel Return On Equity bernilai sebesar 23.790. Hal tersebut dapat diartikan bahwa apabila variabel Return On Equity mengalami kenaikan satu satuan dengan asumsi variabel yang lain tetap (konstan), maka struktur modal akan mengalami penurunan sebesar 23.790 .
5) Koefisien regresi dari variabel pertumbuhan penjualan bernilai sebesar 0.048. Hal tersebut dapat diartikan bahwa apabila variabel pertumbuhan penjualan mengalami kenaikan satu satuan dengan asumsi variabel yang lain tetap (konstan), maka struktur modal akan mengalami penurunan sebesar 0.048 .

b. Uji Koefisien Determinasi (R2)

Uji koefisien determinasi (R2) bertujuan untuk mengukur seberapa jauh kemampuan model dalam menerangkan variasi variabel dependen. Jika nilai R2 yang kecil berarti kemampuan variabelvariabel dependen amat terbatas. Nilai yang mendekati satu berarti variabelvariabel independen memberikan hampir semua informasi yang dibutuhkan untuk memprediksi variasi-variabel dependen. Hasil dari pengujian koefisien determinasi dapat dilihat sebagai berikut :

\begin{tabular}{ccc} 
& \multicolumn{2}{c}{ Tabel 6 Hasil Uji Koefisien Determinasi (R2) } \\
\hline Model & $\begin{array}{c}\text { Adjusted } R \\
\text { Square }\end{array}$ & Keterangan \\
\hline 1 & 0.794 & $\begin{array}{r}\text { Variabel-variabel independen dapat menjelaskan } \\
\text { variasi variabel dependen }\end{array}$ \\
\hline Sumbr & &
\end{tabular}

Sumber : Lampiran

Berdasarkan hasil dari pengujian koefisien determinasi (R2) yang dapat dilihat melalui tabel 8, menunjukkan bahwa adjusted $r$ square sebesar 0.794 . Hal ini dapat diartikan bahwa 79,4\% variasi variabel dependen yaitu struktur modal dapat dijelaskan oleh variabel independen yaitu ukuran perusahaan, pertumbuhan aset, profitabilitas (ROE), dan pertumbuhan penjualan. Sedangkan sisanya yaitu $20,6 \%$ dijelaskan atau dipengaruhi oleh faktor-faktor lain diluar penelitian ini. c. Uji Koefisien Korelasi

Uji koefisien korelasi bertujuan untuk mengukur kekuatan hubungan antara dua variabel atau lebih dengan skala-skala tertentu. Kriteria-kriteria yang disebutkan tentang kekuatan hubungan variabel independen dan variabel dependen yaitu, jika nilai interval koefisien sebesar 0,00 maka tidak ada hubungan yang kuat, jika 0,00-0,25 maka hubungan antara vriabel independen dan dependen sangat lemah, jika 0,25-0,5 maka ada 
hubungan antar keduanya, jika 0,50,75 maka ada hubungan yang kuat antar kedua variabel tersebut, jika 0,75-0,99 maka hubungan antar variabel independen dan dependen tersebut sangat kuat, jika bernilai 1 maka hubungan sempurna positif dan jika bernilai -1 maka sempurna negatif. Hasil pengujian koefisien korelasi dapat dilihat sebagai berikut :

Tabel 7

Hasil Uji Koefisien korelasi

\begin{tabular}{ccccc}
\hline $\begin{array}{c}\text { Variabel } \\
\text { dependen }\end{array}$ & UP & \multicolumn{2}{c}{ Variabel independen } \\
DER & 0.906 & 0.906 & ROE & PP \\
\hline \multirow{2}{*}{ DE } & & & 0.906 & 0.906
\end{tabular}

Sumber : Lampiran

Berdasarkan hasil dari prngujian koefisien korelasi pada tabel 9 diatas, menunjukkan bahwa dari koefisien korelasi dari variabel independen bernilai sebesar 0.906, maka dapat disimpulkan bahwa hubungan antar variabel independen dan variabel dependen sangat kuat. d. Uji Parsial (t)

Uji parsial (t) bertujuan untuk mengetahui seberapa jauh pengaruh dari variabel independen $(\mathrm{X})$ terhadap veriabel dependen (Y) secara parsial. Pengujian hipotesis akan dilakukan dengan menggunakan tingkat signifikasi sebesar 0,05 $(\mathrm{a}=5 \%)$. Hasil dari uji parsial ( $\mathrm{t}$ ) dapat dilihat sebagai berikut :

Tabel 8

Hasil Uji t dan Tingkat Signifikan

\begin{tabular}{cccc}
\hline Model & $\mathrm{t}$ & Sig. & Keterangan \\
\hline UP & -2.075 & 0.048 & Signifikan \\
PA & 1.599 & 0.121 & Tidak Signifikan \\
ROE & 6.861 & 0.000 & Signifikan \\
PP & 0.140 & 0.889 & Tidak Signifikan \\
\hline
\end{tabular}

Sumber: Lampiran

Berdasarkan hasil dari pengujian koefisien korelasi pada tabel 8 di atas, menunjukkan bahwa berpengaruh atau tidaknya variabel independen secara individual terhadap variabel dependen, dapat diuraikan sebagai berikut :

1. Pengaruh Ukuran Perusahaan (X1) terhadap Struktur Modal (Y)

Berdasarkan hasil uji yang dapat dilihat dari tabel 10, menunjukkan bahwa besarnya nilai signifikan dari variabel ukuran perusahaan yang dinyatakan dengan UP yaitu 0,048 . Besar nilai signifikan yang didapat tersebut lebih kecil dari taraf ujinya yaitu $0,048<0,050$, sehingga hipotesis yang pertama dapat diterima yaitu terdapat pengaruh signifikan antara ukuran perusahaan (firm size) terhadap struktur modal.

2. Pengaruh Pertumbuhan Aset $\left(\mathrm{X}_{2}\right)$ terhadap Struktur Modal (Y) 
Berdasarkan hasil uji yang dapat dilihat dari tabel 10, menunjukkan bahwa besarnya nilai signifikan dari variabel pertumbuhan aset yang dinyatakan dengan PA yaitu 0,121. Besar nilai signifikan yang didapat tersebut lebih besar dari taraf ujinya yaitu 0,121>0,050, sehingga hipotesis yang kedua tidak dapat diterima yaitu tidak terdapat pengaruh signifikan antara pertumbuuhan aset (asset growth) terhadap struktur modal.

3. Pengaruh Profitabilitas $\left(\mathrm{X}_{3}\right)$ terhadap Struktur Modal (Y)

Berdasarkan hasil uji yang dapat dilihat dari tabel 10, menunjukkan bahwa besarnya nilai signifikan dari variabel profitabilitas yang dinyatakan dengan ROE yaitu 0,000. Besar nilai signifikan yang didapat tersebut lebih kecil dari taraf ujinya yaitu $0,000<$ 0,050 , sehingga hipotesis yang ketiga dapat diterima yaitu terdapat pengaruh signifikan antara profitabilitas (return on equity) terhadap struktur modal.
4. Pengaruh Pertumbuhan Penjualan (X4) terhadap Struktur Modal (Y)

Berdasarkan hasil uji yang dapat dilihat dari tabel 10, menunjukkan bahwa besarnya nilai signifikan dari variabel pertumbuhan penjualan yang dinyatakan dengan PP yaitu 0,889. Besar nilai signifikan yang didapat tersebut lebih besar dari taraf ujinya yaitu $0,889>0,050$, sehingga hipotesis yang keempat tidak dapat diterima yaitu tidak terdapat pengaruh signifikan pertumbuhan penjualan (sales growth) terhadap struktur modal.

e. Uji Simultan (Uji Statistik F)

Uji Statistik F ini bertujuan untuk menunjukkan apakah semua variabel independen yang dimasukkan dalam model mempunyai pengaruh secara bersama-sama terhadap variabel dependen/terikat. Pada pengujian ini juga menggunakan ketentuan jika nilai $\mathrm{F}$ hitung lebih besar dari pada $\mathrm{F}$ tabel maka Ho ditolak. Pengujian ini juga menggunakan tingkat signifikasi sebesar $5 \%$ atau 0,05 . Hasil dari uji statistik F dapat dilihat sebagai berikut:

Tabel 9

Hasil Uji Simultan (Uji Statistik F)

\begin{tabular}{cccccc}
\hline Model & Fhitung & Ftabel & Sig & Standar & Keterangan \\
\hline 1 & 30.905 & 2.69 & 0.000 & $<0.05$ & H4 diterima \\
\hline Sumber : Lampiran & & &
\end{tabular}

Sumber : Lampiran

Berdasarkan dari hasil pengujian uji F yang dapat dilihat dari tabel 9 diatas dapat diketahui bahwa nilai Fhitung sebesar 30.905, hal tersebut menunjukkan bahwa Fhitung lebih besar dari Ftabel yaitu sebesar 2.69 dan nilai signifikansi sebesar 0.000 jauh lebih kecil dari 0.05 , dari hasil tersebut maka dapat dikatakan bahwa seluruh variabel independen (variabel bebas) secara bersama-sama berpengaruh terhadap variabel dependen (variabel pengikat).

\section{PEMBAHASAN}

Berdasarkan dari seluruh hasil pengujian diatas dapat diuraikan sebagai berikut:

1. Pengaruh ukuran perusahaan (size) terhadap struktur modal

Sesuai dengan hasil yang didapat dari pengujian uji t diperoleh 
nilai signifikan dari variabel ukuran perusahaan yang dinyatakan dengan UP yaitu 0,048. Besar nilai signifikan yang didapat tersebut lebih kecil dari taraf ujinya yaitu $0,048<0,050$, sehingga dapat ditarik kesimpulan bahwa H1 dapat diterima yaitu terdapat pengaruh signifikan antara ukuran perusahaan (firm size) terhadap struktur modal. Penelitian ini memiliki hasil yang sejalan dengan penelitian yang dilakukan oleh Zuhro, F (2016), Sari,A. N. (2016), Nastiti, R. D. (2016), Atiqoh, Z. (2016), yang menyatakan bahwa ukuran perusahaan berpengaruh terhadap struktur modal. Penelitian ini menunjukkan hasil bahwa semakin besar nilai ukuran perusahaan maka semakin besar juga struktur modal pada perusahaan. Dari hasil yang diperoleh, peneliti setuju dengan pernyataan Hanafi (2004:321) bahwa perusahaan yang besar cenderung terdiversivikasi sehingga menurunkan resiko kebangkrutan. Ukuran perusahaan sering dijadikan indikator bagi kemungkinan terjadinya kebangkrutan bagi suatu perusahaan, dimana perusahaan dengan ukuran lebih besar dipandang lebih mampu mengahadapi krisis dalam menjalankan usahanya. Hal ini akan mempermudah perusahaan dengan ukuran besar untuk memperoleh pinjaman dari kreditur. Sehingga dapat ditarik kesimpulan apabila semakin besar ukuran perusahaan maka semakin besar juga struktur modal dalam perusahaan.

2. Pengaruh pertumbuhan aset (asset growth) terhadap struktur modal

Sesuai dengan hasil yang didapat dari pengujian uji $\mathrm{t}$ diperoleh nilai signifikan dari variabel pertumbuhan aset yang dinyatakan dengan PA yaitu 0,121. Besar nilai signifikan yang didapat tersebut lebih besar dari taraf ujinya yaitu 00,121 > 0,050, sehingga H2 tidak dapat diterima, maka dapat ditarik kesimpulan yaitu tidak terdapat pengaruh signifikan antara ukuran pertumbuhan aset (asset growth) terhadap struktur modal. Hasil ini sejalan dengan penelitian sebelumnya yaitu Zuhro, F (2016), Sari,A. N. (2016), yang menyatakan bahwa tidak terdapat pengaruh terhadap struktur modal. Hasil penelitian ini menunjukkan bahwa semakin tinggi nilai pertumbuhan aset maka semakin rendah struktur modal di dalam perusahaan. Hal ini dikarenakan besarnya pertumbuhan aset perusahaan karena kemampuan perusahaan dalam melakukan peningkatan sales. Dengan meningkatnya sales perusahaan, maka perusahaan dapat mempunyai dana yang lebih untuk memenuhi kebutuhan, sehingga dapat disimpulkan semakin besar pertumbuhan aset maka struktur modal perusahaan semakin rendah.

3. Pengaruh profitabilitas (return on equity) terhadap struktur modal

Sesuai dengan hasil yang didapat dari pengujian uji t diperoleh nilai signifikan dari variabel profitabilitas yang dinyatakan dengan ROE yaitu 0,000. Besar nilai signifikan yang didapat tersebut lebih kecil dari taraf ujinya yaitu $0,000<0,050$, sehingga H3 dapat diterima yaitu terdapat pengaruh signifikan antara profitabilitas terhadap struktur modal. Hasil dari penelitian ini sependapat 
dengan penelitian sebelumnya yaitu Zuhro, F (2016), yang menyatakan bahwa profitabilitas berpengaruh terhadap struktur modal. Namun penelitian ini tidak sependapat dengan penelitian sebelumnya yaitu Sari,A. N. (2016), Nastiti, R. D. (2016), Atiqoh, Z. (2016), yang menyatakan bahwa profitabilitas berpengaruh tidak signifikan terhadap struktur modal. Hasil penelitian ini menjelaskan bahwa semakin besar nilai profitabilitas maka struktur modal juga akan semakin besar. Hal ini dikarenakan karna profitabilitas menunjukkan kemampuan memperoleh laba. Dengan laba yang diperoleh semakin tinggi, maka memungkinkan untuk penawaran hutang yang semakin tinggi, dikarenakan tingkat kepercayaan kreditu terhadap perusahaan semakin besar. Jadi dapat disimpulkan bahwa semakin tinggi profitabilitas yang dimiliki perusahaan akan semakin besar juga struktur modal di dalam perusahaan.

4. Pengaruh pertumbuhan penjualan (sales growth) terhadap struktur modal

Sesuai dengan hasil yang didapat dari pengujian uji t diperoleh nilai signifikan dari variabel pertumbuhan penjualan yang dinyatakan dengan PP yaitu 0,889. Besar nilai signifikan yang didapat tersebut lebih besar dari taraf ujinya yaitu $0,889>0,050$, sehingga $\mathrm{H} 4$ tidak dapat diterima yaitu tidak terdapat pengaruh signifikan antara ukuran perusahaan terhadap struktur modal. Hasil penelitian ini sejalan dengan penelitian sebelumnya yaitu Nastiti, R. D. (2016), Atiqoh, Z. (2016), yang menyatakan bahwa tidak ada pengaruh yang signifikan antara pertumbuhan penjualan terhadap struktur modal. Hal ini dikarenakan pertumbuhan penjualan yang tinggi atau stabil saling berkaitan dengan keuntungan perusahaan. Dengan tingkat pertumbuhan penjualan yang tinggi atau stabil dapat berpengaruh terhadap keuntungan perusahaan sehingga menjadi petimbangan perusahaan dalam menentukan struktur modal, hal tersebut berpengaruh terhadap hutang yang dimiliki perusahaan, perusahaan dapat memenuhi sebagian kebutuhan dengan keuntungan perusahaan. Maka dapat ditarrik kesimpulan bahwa semakin tinggi pertumbuhan penjualan maka semakin rendah struktur modal di dalam perusahaan.

5. Pengaruh ukuran perusahaan (size), pertumbuhan aset (asset growth), profitabilitas (return on equity), dan pertumbuhan penjualan (sales growth) terhadap struktur modal (debt to equity ratio)

Berdasarkan hasil pengujian uji $\mathrm{F}$ diperoleh dari Fhitung sebesar 30.905, nilai Ftabel diperoleh sebesar 2.69, yang artinya Fhitung > Ftabel dan nilai signifikansi sebesar 0.000 , yang dapat diartikan nilai signifikansi < 0.05. Maka dapat ditarik kesimpulan bahwa variabel independen (variabel bebas) yang digunakan dalam penelitian ini yaitu ukuran perusahaan, pertumbuhan aset, profitabilitas, dan pertumbuhan penjualan secara simultan berpengaruh terhadap variabel dependen yaitu struktur modal. Hasil yang diperoleh sejalan dengan penelitian sebelumnya yaitu penelitian 
yang dilakukan oleh Zuhro, F (2016), Sari,A. N. (2016), Nastiti, R. D. (2016), Atiqoh, Z. (2016), yang menyatakan bahwa terdapat pengaruh secara signifikan antara variabel bebas (variabel independen) terhadap variabel pengikat (dependen). Sehingga hal ini menunjukkan bahwa pada penelitian tidak banyak mengalami perbedaan terhadap penelitian lainnya atau penelitian sebelumnya, dikarenakan persamaan sektor perusahaan yang dipilih oleh peneliti dengan perbedaan jumlah perusahaan yang diambil dan perbedaan yang tidak begitu banyak pada tahun penelitian.

\section{KESIMPULAN}

Penelitian ini memiliki tujuan untuk mengetahui apakah terjadi pegaruh antara ukuran perusahaan (firm size), pertumbuhan aset (assets growth), profitabilitas (return on equity), dan pertumbuhan penjualan (sales growth) terhadap struktur modal (debt equity ratio) pada perusahaan Go Public yaitu di sektor Cosmetics and Houshold yang terdaftar Bursa Efek Indonesia (BEI). Jumlah sampel yang digunakan dalam penelitian ini 6 perusahaan dengan laporan keuangan diantara tahun 2010 sampai tahun 2015. Hasil yang didapatkan dari pengujian secara parsial dapat diketahui bahwa variabel ukuran perusahaan berpengaruh signifikan terhadap struktur modal, hasil yang didapat tersebut sejalan dengan penelitian yang dilakukan oleh Zuhro, F (2016), Sari,A. N. (2016), Nastiti, R. D. (2016), Atiqoh, Z. (2016). Variabel pertumbuhan aset tidak berpengaruh signifikan terhadap struktur modal, hasil penelitian tersebut sejalan dengan Zuhro, F
(2016), Sari,A. N. (2016). Variabel profitabilitas berpengaruh secara signifikan terhadap struktur modal, hasil dari penelitian tersebut sejalan dengan penelitian Zuhro, (2016). Variabel pertumbuhan penjualan diketahui tidak mempunyai pengaruh yang signifikan terhadap struktur modal, hasil tersebut sejalan dengan penelitian yang dilakukan oleh Nastiti, (2016), Atiqoh, (2016). Sedangkan hasil yang diperoleh dari pengujian secara simultan yaitu variabel independen (variabel bebas) yang digunakan dalam penelitian ini (ukuran perusahaan, pertumbuhan aset, profitabilitas, pertumbuhan penjualan) berpengaruh signifikan terhadap variabel dependen (variabel pengikat) yaitu struktur modal, hasil penelitian ini sejalan dengan penelitian dari Zuhro, F (2016), Sari, A. N. (2016), Nastiti, R. D. (2016), Atiqoh, Z. (2016).

\section{DAFTAR PUSTAKA}

Aji, D. Y., Mita, A. F. (2010). Pengaruh Profitabilitas, Risiko Keuangan, Nilai Perusahaan, Dan Struktur Kepemilikan Terhadap Praktek Perataan Laba: Studi Empiris Perusahaan Manufaktur Yang Terdaftar di BEI. Simposium Nasional Akuntansi XIII Purwokerto.

Atiqoh, Z. (2016). Pengaruh Kinerja Keuangan, Size, Pertumbuhan Penjualan, Dan Kepemilikan Saham Terhadap Struktur Modal. Jurnal Ilmu Dan Riset Akuntansi, 5(5).

Brigham, and Ehrhardt. 2005. Financial Management : Theory And Practice, Eleventh Edition, Thomson South- 
Western Ohio, United States Of America.

Brigham, E.F. dan J. F. Houston. 2009. Dasardasar Manajemen Keuangan. Edisi Sepuluh. Salemba Empat. Jakarta.

Brigham, E.F. dan J.F. Houston. 2006. Fundamentals of Financial Management. Tenth Edition. Cengange Learning Asia. Singapore. Terjemahan A.A. Yulianto. Dasar-dasar Manajemen Keuangan. Edisi Kesepuluh. Jilid dua. Salemba Empat. Jakarta.

Brigham, F. Eugene and F. J. Houston. 2001. Manajemen Keuangan,Edisi 8, Edisi Indonesia.Jakarta : Erlangga.

Fatmawati, Nurlaela. (2015, September). Kemampuan Earnings, Book Value Of Equity, Dan Cash Flow Dalam Memprediksi Return Saham. Seminar Nasional Uniba Surakarta 2015.

Ghozali, I. 2011. Aplikasi Analisis Multivariate dengan Program SPSS. Badan Penerbit Universitas Diponegoro. Semarang.

Maryanti, E. (2016). Analisis Profitabilitas, Pertumbuhan Perusahaan, Pertumbuhan Penjualan Dan Struktur Aktiva Terhadap Struktur Modal Pada Perusahaan Sektor Industri Barang Konsumsi Yang Terdaftar Di Bursa Efek Indonesia. Riset Akuntansi Dan Keuangan Indonesia, l(2), 156-167.

Moeljadi, L. 2006. Manjemen Keuangan Pendekatan Kuantitatif dan Kualitatif. Edisi Pertama.Bayumedia Publishing. Malang.

Nastiti, R. D. (2016). Pengaruh Struktur Aset, Likuiditas, Profitabilitas, Ukuran Perusahaan, Pertumbuhan Penjualan
Terhadap Struktur Modal. Jurnal Ilmu Dan Riset Akuntansi, 5(1).

Pramesti, Nurlaela. (2016). Pengaruh Rasio Likuiditas, Leverage, Aktivitas Dan Firm Size Terhadap Profitabilitas Perusahaan Sub Sektor Otomotif Dan Komponen Di Bursa Efek Indonesia. Prosiding IENACO Universitas Muhammadiyah Surakarta.

Priambodo, T. J., Topowijono, dan D. F. Azizah. 2014. Pengaruh Struktur Aktiva, Tingkat Pertumbuhan Penjualan dan Profitabilitas Terhadap Struktur Modal. Jurnal Administrasi Bisnis. Vol. 9.

Putri, Nurlaela. (2015), Pengaruh Rasio Keuangan Terhadap Pertumbuhan Laba Pada Perusahaan Pertambangan Di Bursa Efek Indonesia. In Seminar Nasional Uniba Surakarta 2015.

Rahadia, Titisari, Nurlaela. (2013). Pengaruh Likuiditas, Profitabilitas, Solvabilitas, Dan Ukuran Perusahaan Terhadap Harga Saham Pada Perusahaan Manufaktur Yang Terdaftar Di Bursa Efek Indonesia. Jurnal Paradigma, 11(01).

Riyanto, B. 2011. Dasar-dasar Pembelanjaan Perusahaan. Edisi Keempat.BPFE. Yogyakarta.

Rizqia, D. A., Aisjah dan Sumiati, S. (2013). Effect of Managerial Ownership, Financial Leverage, Profitability, Firm Size, and Investment Opportunity on Dividend Policy and Firm Value. Research Journal of Finance and Accounting Vol, 4, 120-130.

Rudianto. (2009). Akuntansi Manajemen.Grasindo. Yogyakarta. 
Sari, A. N. (2016). Pengaruh Profitabilitas, Likuiditas, Pertumbuhan Aset Dan Ukuran Perusahaan Terhadap Struktur Modal. Jurnal Ilmu \& Riset Manajemen, 5(4).

Sartono, R. A. 2001. Manajemen Keuangan Teori dan Aplikasi. BPFE, Yogyakarta.

Sartono, R. A. 2008. Manajemen Keuangan, Teori dan Aplikasi. Edisi 4, BPFE, Yogyakarta.

Sarwono, J. 2006. Metode Penelitian Kuantitatif dan Kualitatif. Yogyakarta: Graha Ilmu.

Sjahrial, D. 2007. Manajemen Keuangan, Edisi Pertama. Jakarta : Mitra Wacana Media.

Sulistiyowati, I., Anggraini, R., \& Utaminingtyas, T. H. (2010). Pengaruh Profitabilitas, Leverage, dan Growth Terhadap Kebijakan Dividen dengan Good Corporate Governance sebagai Variabel Intervening. Simposium Nasional Akuntansi XIII Purwokerto.

Suliyanto. 2011. Ekonometrika Terapan: Teori dan Aplikasi Dengan SPSS. Penerbit Andi.Yogyakarta.

Trisnawati, R., \& Nugraheni, D. The Analysis Of Information Asymmetry, Profitability, And Deferred Tax Expense On Integrated Earning Management. http://seajbel.com/wpcontent/uploads/2016/01/Acc-15.pdf.

Watung, A. K. S. (2016). Pengaruh Rasio Likuiditas, Aktivitas, Profitabilitas, Dan Struktur Aktiva Terhadap Struktur Modal Industri Barang Konsumsi Di Bursa Efek Indonesia. Jurnal Riset Ekonomi, Manajemen, Bisnis Dan Akuntansi, 4(2).
Weston J. F. dan T. E. Copeland. 2008. Manajemen Keuangan. Binarupa Aksara. Jakarta.

Widiastuti, N. A., Arifati, R., \& Oemar, A. (2016). Pengaruh Leverage, Ukuran Perusahaan, Pertumbuhan Perusahaan, Rasio Likuiditas Dan Rasio Aktivitas Terhadap Profitabilitas (Studi Pada Sektor Keuangan dan Perbankan di BEI Tahun 2010-2014). Journal Of Accounting, 2(2).

W Rizkanella, Nurlaela.2016. Pengaruh Leverage, Likuiditas, Aktivitas Dan Sales Growth Terhadap Kondisi Financial Distress Pada Perusahaan Manufaktur Barang Konsumsi Di Bei. Icaf Umy 2 (2016) : 39-53.

Zuhro, F. (2016). Pengaruh Ukuran Perusahaan, Pertumbuhan Aset, Dan Profitabilitas Terhadap Struktur Modal. Jurnal Ilmu \& Riset Manajemen, 5(5). 